\title{
Film title conventions
}

Title details observe archival practice in cataloguing, as set out by FIAF (International Federation of Film Archives). [ ] indicate an attributed title for cataloguing purposes, where there is no evidence of a prior existing title; * or hyphenated dates indicates the approximate date of the filmstock, and may represent a date earlier than when the film was made. 
Heather Norris Nicholson - 9781526141187 Downloaded from manchesterhive.com at 04/26/2023 05:09:38AM via free access 